\title{
Improvement yield of applewood (Feronia limonia) flavor extract by liquid-liquid extraction with dichloromethane solvent
}

\author{
Agus SUYANTO ${ }^{1,2 *}\left(\mathbb{0}\right.$, Erliza NOOR ${ }^{3}$, Meika Syahbana RUSLI ${ }^{3}$, Farah FAHMA ${ }^{3}$
}

\begin{abstract}
Applewood (Feronia limonia) or 'Kawista' in Indonesia is a rare plant with a unique flavor. The research objective is to optimize the extraction process to get the best Applewood Flavor Extract (AFE) using a mono-factor design. Extraction was carried out in two stages; firstly, it was maceration with dichloromethane, glycerin, and alcohol solvents. Secondly, liquid-liquid extraction (LLE) with dichloromethane solvent. The best results are based on sensory values, and UV-Vis analysis on maceration alcohol (70\%) is 18 hours with stirring. The best LLE at 12 hours was obtained from alcohol-dichloromethane (ALC-DCM) extract with a yield $28.55 \%$ fruit pulp base. The ALC-DCM extract was then analyzed by the chemical components of GC-MS, LC-MS/MS, and sensory of the Quantitative Descriptive Analysis (QDA) method. GC-MS analysis succeeded in characterizing 91 volatile compounds. LLE technique of ALC-DCM extract can increase the absorption of ester compounds by $66.67 \%$ compare with dichloromethane (DCM) extract. There are 30 organic compounds from LC-MS/MS analysis. The volatile chemical marker on ALC-DCM extract with Principal Component Analysis (PCA) is the ester, and the aroma marker from QDA is apple-like and vinegar.
\end{abstract}

Keywords: Applewood flavor extract; LLE; QDA; PCA; GC-MS; LC-MS/MS.

Practical Application: Applewood flavor extract is a natural raw material for agro-industrial, especially for food.

\section{Introduction}

The use of natural foodstuffs continues to increase along with the increasing awareness of the people to consume safe and nutritious food that has a positive impact on health. Applewood (Feronia limonia) is classified as a rare plant and has a distinctive aroma. In Indonesia, it can be found in Aceh, Rembang, and Bima. Applewood fruit that is perfectly ripe has a distinctive aroma and can give food flavor. Natural flavor has several advantages, in addition to providing flavor to the product, it also has a function for health (Berger, 2009). Natural flavorforming compounds are good for health and extend product shelf life (Ayseli \& İpek Ayseli, 2016). The demand for natural flavors by consumers in beverage industry products continues to increase (Zegler, 2012).

Based on the raw material, flavors can be classified into three types: natural flavor, identical natural flavor, and artificial flavor. Natural flavors are compounds that are extracted from ingredients that exist in nature. Natural identical flavors are compounds that are found in nature but are made synthetically or chemically. Artificial flavors are compounds that do not exist in nature and can only be made synthetically (Heath, 1978).
Analysis with Gas Chromatography-Mass SpectrometryOlfactometry (GC-MS-O) to identify and describe the character impact odorants of applewood fruit flavor, obtained specific aromas, namely fruity, sweet, melon-like, cheese (butter-like), herbaceous (green), and sour aroma. GC-MS successfully identified 75 volatile components of applewood consisting of esters, alcohol, aldehyde, ketones, carboxylic acids, lactones, hydrocarbons, acetals, heterocyclic aromatics, and furans (Apriyantono \& Kumara, 2004).

Some volatile components are small, less than the detection limit of analytical instruments, but can be detected by the human olfactory (Goff \& Klee, 2006). Many factors can affect the composition of volatile components in fruit such as genetics, degree of maturity, environmental conditions, handling after harvest, and storage (El Hadi et al., 2013).

The extraction process is essential because it will determine the extracted components. According to Ormeño et al. (2011), until now, there is no consensus which states that the extraction method is best for extracting a volatile component. Several extraction methods have been developed to obtain flavor 
components, including using a solvent (maceration), vacuum distillation, Likens-Nickerson distillation, and headspace. The determination of the best method was carried out on the extract by scoring tests by semi-trained panelists.

Some of the flavor extraction techniques are extraction to characterize the flavor. The results obtained were flavor extracts with tiny yield. The research challenge is how to obtain a flavor extract that is similar to real fruit and has a high yield so that it can be applied in industry. The research objective was to select the best extraction technique for AFE to produce high yield and best flavor sensory and chemical.

\section{Materials and methods}

\subsection{Materials}

The research materials were ripe Applewood fruit from Rembang Regency of Central Java Province of Indonesia, alcohol, glycerin, aquadest, dichloromethane, $\mathrm{Na}_{2} \mathrm{SO}_{4}$ anhydrous, flavor samples (Hexyl acetate, Benzyl acetate, Maltol, Trans-2-hexenal, Aldehyde C8, Acetyl pyridine) from PT Firmenich Indonesia.

\subsection{Selection of panelists}

Panelist selection aims to get semi-trained panelists in sensory tests who have a sensitivity to smell scents and select the triangular test method using standard aroma (Setyaningsih et al., 2010). The number of panelists selected was 10 out of 27 panelists who took part in the selection with a score above 75 . The samples were tested sequentially. The identification of this standard aroma was carried out three times.

\subsection{Maceration extraction procedure of $A F E$}

Applewood fruit is broken down, then peel and seeds are separated so that the applewood pulp is obtained. $100 \mathrm{~g}$ applewood pulp is added with dichloromethane solvent (1:1); glycerin (1:1.5) at a concentration of $25 \%, 50 \%, 75 \%$, and $100 \%$; and alcohol solvent (1:4) at a concentration of $50 \%, 70 \%$, and $96 \%$. The extraction process is carried out for 12-24 hours at 6 hours interval and stirring treatment/without stirring (magnetic stirrer). Furthermore, the solution is filtered with a filter size of 400 mesh. The filtrate was added with anhydrous $\mathrm{Na}_{2} \mathrm{SO}_{4}$ to remove water in the sample (dichloromethane and alcohol solvents), followed by evaporating the solvent using a rotary vacuum evaporator (rotavapor). Glycerin is not evaporated because it is thick/sticky. Finally, each extract, namely the DCM extract, glycerin extract (GLY), and alcohol extract (ALC), was analyzed for the sensory scoring value, the absorbance value (190-320nm wavelength spectrophotometer) the analysis of volatile chemical components using GC-MS.

\subsection{LLE procedure of $A F E$}

Sample $30 \mathrm{ml}$ of alcohol extract (without concentration) and dichloromethane solvent (1:0.5) were extracted for 12 hours (without stirring), stirring for 6 hours, 12 hours, and 18 hours. A decantation process separates the filtrate (dichloromethane) and raffinate (alcohol), then the solvent (dichloromethane) is evaporated using a rotavapor. ALC-DCM extract was analyzed for absorbance values (spectrophotometer wavelength 190$320 \mathrm{~nm}$ ), followed by an analysis of sensory values (similarity, preferences, and QDA), extraction yields, and chemical analysis components using GC-MS and LC-MS/MS.

\subsection{Statistical analysis}

The research data was visualized descriptively, including data tabulation and figure presentation. The statistical test used multivariate analysis with the PCA method on the results of chemical and sensory analysis. According to Setyaningsih et al. (2010), PCA is a multivariate analysis method that can transform original variables into new variables, linear combinations of the original variables called Principal Components. PCA can explain $75 \%-90 \%$ of the data total diversity with only $2-3$ main components. Sensory analysis of the sample used a QDA by semi-trained panelists.

\section{Results and discussion}

\subsection{Extraction of AFE}

The extraction of the non-polar solvent maceration method was chosen as the flavor extraction method of applewood fruit. It has the highest similarity score for fresh fruit, compared to the extraction technique of the Likens Nickerson method, Head Space, Vacuum Distillation. Dichloromethane was chosen as the best solvent compared to diethyl ether, dichloromethane: pentane (1:1), and pentane (Apriyantono \& Kumara, 2004). The ratio of the substance to the solvent is 1:1 (Lindawati, 1995; Septiana, 1995; Laarsen \& Poll, 1990).

The material, namely Applewood fruit, is not dried and reduced in size as in many extraction studies, because the dried fruit has less aroma (Ardila \& Noor, 2020). In this study, the dichloromethane solvent can be used as a control treatment for the standard applewood fruit flavor. Furthermore, other solvent alternatives are sought to obtain an extract product that is ready for use in industry. Glycerin and alcohol solvents were selected to extract the applewood flavor and optimize the solvent concentration and maceration time. The sensory evaluation of GLY extract by semi-trained panelists obtained the highest similarity score for fresh fruit aroma at 50\% glycerin concentration with a score of 4.36 (Figure 1A).

The alcohol extract that has been evaporated by the solvent has a higher score than that without evaporation. The best solvent evaporated alcohol extract was at a $70 \%$ concentration, with a score of 5 (Figure 1B). Optimization of the extraction was carried out with maceration time with $500 \mathrm{rpm}$ stirring for 6-24 hours at 6 hours interval. Qualitative analysis of the extracted volatile components using UV-Vis $190-320 \mathrm{~nm}$ obtained the highest absorption at 18 hours stirring, namely 3240 (Figure 1C).

\subsection{LLE of the ALC extract with dichloromethane solvent}

LLE of the alcohol extract with a dichloromethane solvent aims to absorb the flavor of applewood. Evaluation of the 
A

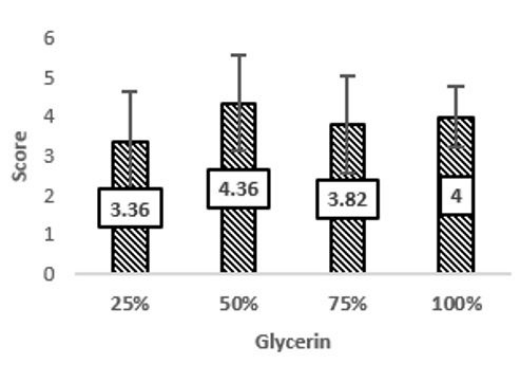

B

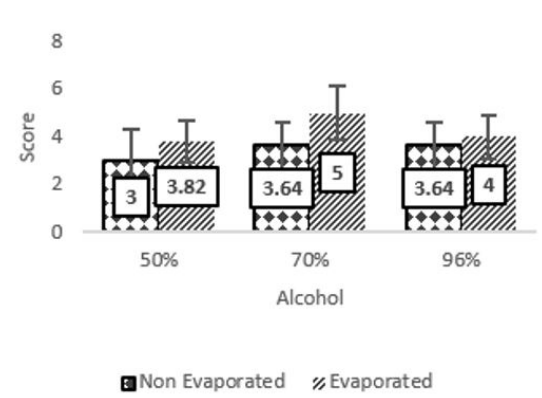

$\mathrm{C}$

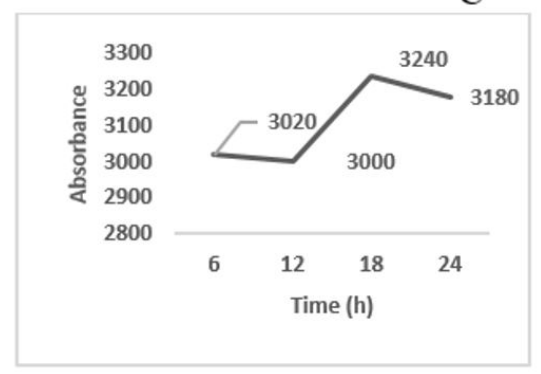

Figure 1. The sensory scoring test results of glycerin extract (A), alcohol extract (B) and the absorbance of volatile compounds of alcohol extract (C).

extraction treatment, namely the extraction time and stirring treatment, was based on the adsorption of volatile compounds at $190-320 \mathrm{~nm}$. The lowest absorbance in control was without stirring, and the extraction time was 12 hours, namely 3010, and the highest absorbance was at stirring with an extraction time of 18 hours, which was 3710 (Figure 2A).

The evaluation of the next extraction is based on the extraction yield. Figure $2 \mathrm{~B}$ shows the highest yield with stirring extraction time of 12 hours, namely $28.55 \%$ (pulp). Several things that must be considered in increasing the yield of LLE are the solvent-feed ratio, extraction time, and stirring speed (Martunus \& Helwani, 2006).

The ALC-DCM extract was compared to sensory and volatile compounds with DCM extract and glycerin extract (GLY). The sensory test results for the similarity score and the highest preference score in the DCM extract were 5, and the ALC-DCM extract scored 4.5 and 4.7 (Figure 2C). The ALC-DCM extract has the potential to be developed because it has a high yield, similarity score, and preference score.

\subsection{The volatile compound of AFE by GC-MS}

In Table 1, it can be seen that as many as 91 volatile chemical compounds were found in AFE with different solvent extraction techniques, namely dichloromethane, glycerin, and alcohol-dichloromethane. Types of chemical compounds are grouped based on their groups, then quantified the percentage of compounds, the number of compounds, and the total compounds per group.

Esters dominated by methyl and ethyl series in this study are the same as previous studies (Apriyantono \& Kumara, 2004). The aromas that play a role in the applewood of Sri Lanka flavor are butanoic acid, methyl butanoate, and ethyl 3-hydroxyhexanoate in fresh fruit and cream products and overall give a delicious aroma (MacLeod \& Pieris, 1981).

The ethyl butyrate component found in applewood fruit is also found in the Baladi mango from Egypt. Ethyl butanoate with a banana-like aroma is the main ester component in the mango (Engel \& Tressl, 1983). Butyl acetate has a fruity (pearlike) aroma and is the main ester component of mountain papaya from Chile. The aromas of fruity (pear-like) applewood flavor are components of citronella formate and ethyl octanoate. Esters that play a role in papaya's flavor characteristics are methyl butyrate and ethyl butyrate (Idstein et al., 1985). The butanoic acid component in the applewood flavor gives it a cheesy or butter-like aroma. This butanoic acid component is also found in mangoes and papayas, which give it a rancid butter-like aroma (Yamaguchi et al., 1993).

Figure $3 \mathrm{~A}$ shows that the three extracts' concentration is dominated by the highest carboxylic acid group of ALC-DCM extract, followed by GLY extract and DCM extract; 89\%,
A

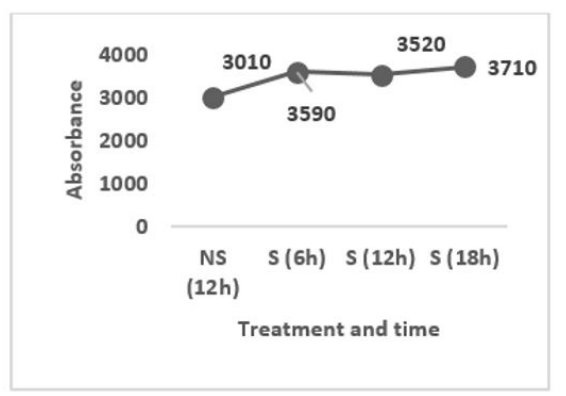

B

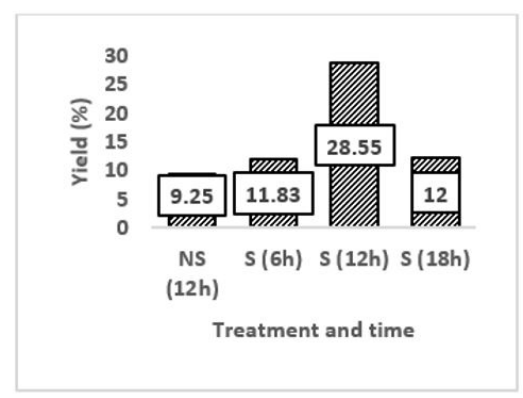

$\mathrm{C}$

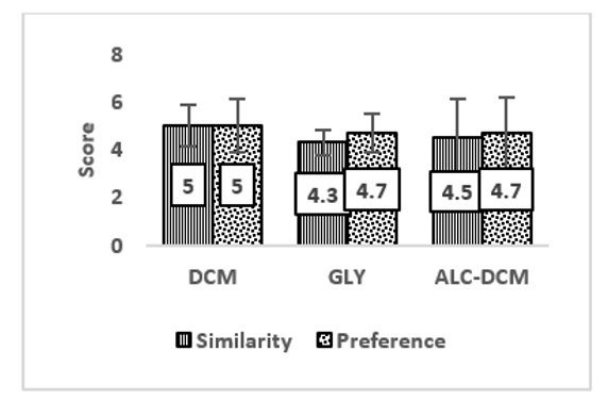

Figure 2. Absorbance of volatile compounds of ALC-DCM (A) extract, a yield of ALC-DCM (B) extract, and sensory scoring test of similarities and preferences of DCM, GLY, and ALC-DCM extracts (C). Information: NS (Non stirrer), S (Stirrer), h (hour). 
Table 1. Volatile compounds extract of DCM, GLY, and ALC-DCM results from GC-MS analysis and details in percent concentration of compounds per group, amount of compounds, and total compounds per group.

\begin{tabular}{|c|c|c|c|c|c|}
\hline No & Code & Name of Compound & DCM & GLY & ALC-DCM \\
\hline \multicolumn{6}{|c|}{ Ester } \\
\hline 1 & E1 & Ethyl 3 Hydroxy Butyrate & nd & 2.45 & nd \\
\hline 2 & E2 & Hexanoic acid, 3-hydroxy-, methyl ester & 3.22 & 0.33 & nd \\
\hline 3 & E3 & Hexanoic acid, 2-methylbutyl ester & nd & 0.48 & nd \\
\hline 4 & E4 & 9-Octadecenoic acid (Z)-, octadecyl ester & nd & 0.12 & nd \\
\hline 5 & E5 & hexanoic acid methyl ester & 0.72 & nd & 0.1 \\
\hline 6 & E6 & Hexanoic acid, ethyl ester & nd & nd & 0.2 \\
\hline 7 & E7 & Hexanoic acid, 3-hydroxy-, ethyl ester & 2.21 & nd & 0.24 \\
\hline 8 & E8 & Ethyl acetoacetate & 0.36 & nd & nd \\
\hline 9 & E9 & n-Propyl 9-octadecenoate & 0.2 & nd & nd \\
\hline 10 & E10 & Octatriacontyl pentafluoropropionate & 0.08 & nd & nd \\
\hline 11 & E11 & Butanoic acid, 3-hydroxy-, ethyl ester & nd & nd & 0.62 \\
\hline 12 & E12 & .alpha.-D-Mannopyranoside, methyl 3,6-anhydro- & nd & nd & 0.39 \\
\hline 13 & E13 & 1-Nitro-.beta.-d-arabinofuranose, tetraacetate & nd & nd & 0.2 \\
\hline 14 & E14 & Hexadecanoic acid, ethyl ester & nd & nd & 0.26 \\
\hline 15 & E15 & 9-Octadecenoic acid, methyl ester, (E)- & nd & nd & 0.16 \\
\hline 16 & E16 & (E)-9-Octadecenoic acid ethyl ester & nd & nd & 1.17 \\
\hline \multirow[t]{4}{*}{17} & E17 & Cheilanth-13(14)-enic Methyl Ester & nd & nd & 0.07 \\
\hline & & Concentration $(\%)^{*}$ & 6.79 & 3.38 & 3.41 \\
\hline & & Amount of compounds $(\%)^{* *}$ & 13.64 & 11.11 & 28.57 \\
\hline & & Ester total $(\%)^{* * *}$ & 35.29 & 29.41 & 58.82 \\
\hline \multicolumn{6}{|c|}{ Alcohol } \\
\hline 18 & $\mathrm{C} 1$ & a monoterpene alcohol & 4.9 & 1.52 & nd \\
\hline 19 & $\mathrm{C} 2$ & 1-Hexanol & 1.72 & 0.48 & 0.2 \\
\hline 20 & $\mathrm{C} 3$ & 2,4-Pentanediol (CAS) & 1.53 & 1.2 & 0.74 \\
\hline 21 & $\mathrm{C} 4$ & 1,2-Propanediol & nd & 0.05 & 0.27 \\
\hline 22 & $\mathrm{C} 5$ & 6,7-Dehydro-7,8-Dihydro-3-Oxo-.Alpha.-Ionol & nd & 0.12 & nd \\
\hline 23 & C6 & trans-Sinapyl alcohol & nd & 0.21 & nd \\
\hline 24 & $\mathrm{C} 7$ & (3methyl, 24S)- stigmast-5-en-3-ol & nd & 0.1 & nd \\
\hline 25 & $\mathrm{C} 8$ & 3(2-Hydroxyethyl)-1,2-Ethylidene Glycerol & nd & 0.13 & nd \\
\hline 26 & C9 & m-Cresol, 6-tert-butyl- & 0.34 & nd & nd \\
\hline 27 & $\mathrm{C} 10$ & Propylene Glycol & 0.12 & nd & nd \\
\hline 28 & $\mathrm{C} 11$ & Phenylethyl Alcohol & 0.83 & nd & nd \\
\hline 29 & $\mathrm{C} 12$ & 3-Hydroxy-4-methoxybenzyl alcohol & 0.16 & nd & nd \\
\hline 30 & $\mathrm{C} 13$ & (3methyl, 24S)- stigmast-5-en-3-ol & 0.71 & nd & nd \\
\hline 31 & $\mathrm{C} 14$ & Phloroglucitol & nd & nd & 0.29 \\
\hline \multirow[t]{4}{*}{32} & $\mathrm{C} 15$ & Pluchidiol & nd & nd & 0.15 \\
\hline & & Concentration $(\%)^{*}$ & 10.31 & 3.81 & 1.65 \\
\hline & & Amount of compounds $(\%)^{* *}$ & 18.18 & 17.78 & 14.29 \\
\hline & & Alcohol total $(\%)^{* * *}$ & 53.33 & 53.33 & 33.33 \\
\hline \multicolumn{6}{|c|}{ Carboxylic acid } \\
\hline 33 & A1 & Sorbic Acid & nd & 67.66 & nd \\
\hline 34 & $\mathrm{~A} 2$ & Myristic acid & 0.88 & 0.22 & 0.73 \\
\hline 35 & A3 & trans-Cinnamic acid & 0.09 & nd & nd \\
\hline
\end{tabular}


Original Article

Suyanto et al.

Table 1. Continued....

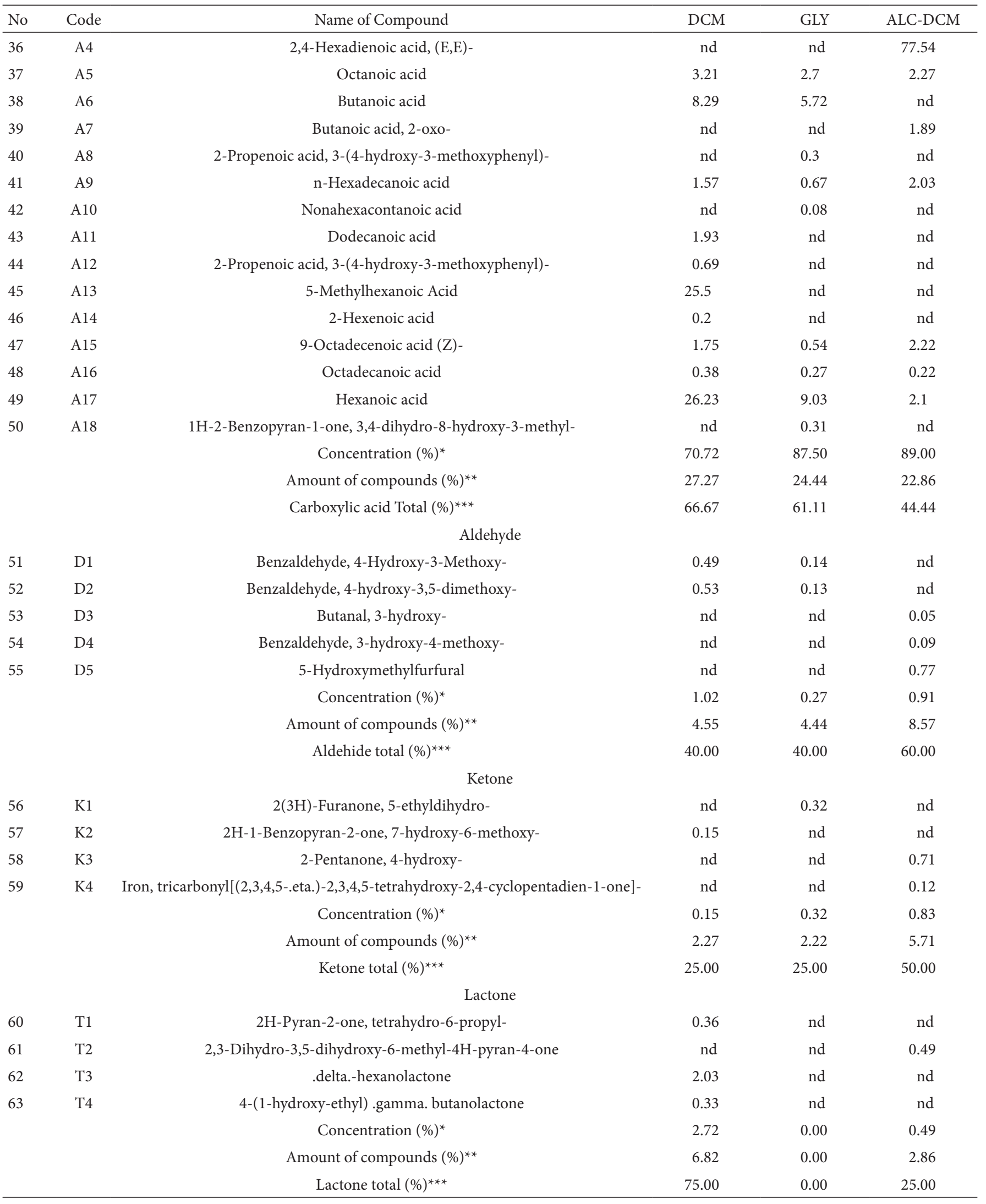


Table 1. Continued....

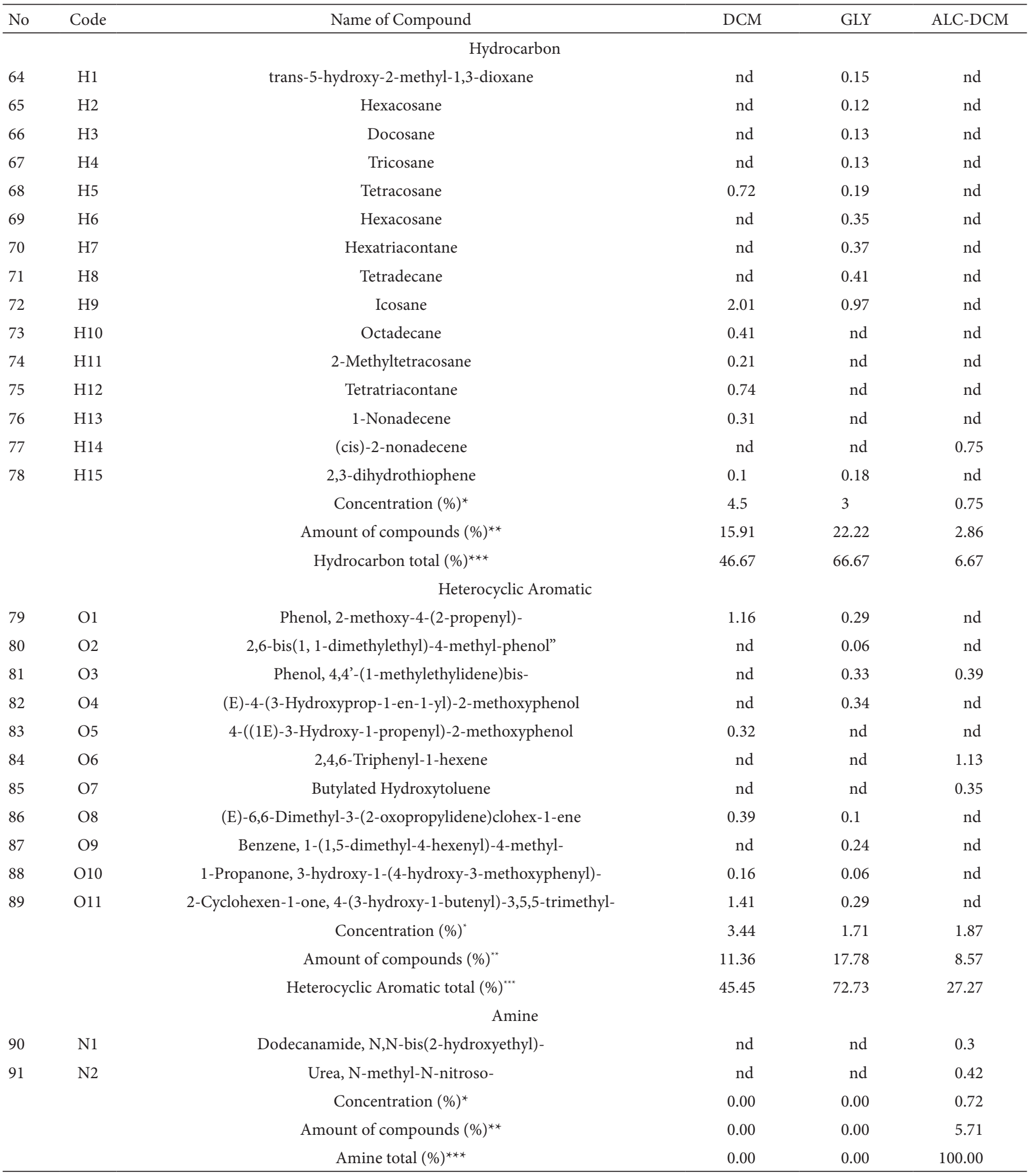

Description of Component code: E (Ester), C (Alcohol), A (Carboxylic Acid), D (Aldehyde), K (Ketone), T (Lactone), H (Hydrocarbon), O (heterocyclic aromatic), N (amine). nd: not detected; ${ }^{*}$ concentration in percent based on the peak area of the compound detected by GC-MS; ${ }^{*}$ Percentage of the amounts of volatile components detected by GC-MS; ${ }^{* *}$ Total components per group in percent detected by GC-MS. 
$87.5 \%$, and $70.72 \%$, respectively. The highest ester compound was in the DCM extract, followed by the ALC-DCM and GLY extracts; $6.31 \%, 3.41 \%$, and $3.38 \%$, respectively. Carboxylic acid components are commonly found in fruits and give a sour aroma (Yamaguchi et al., 1993) (see table 1). Based on PCA analysis (Figure 3B), the marker compounds of ALC-DCM Extract are A4 (2,4-Hexadienoic acid, (E, E) -), A5 (Octanoic acid), A9 (n-Hexadecanoic acid), and A15 (9- Octadecenoic acid (Z) -).

The concentration of ester compounds is 3.38-6.31\%, but the ester gives an aroma with high Flavor Dilution (FD) so that it plays a role in the formation of applewood flavor. Ethyl butyrate ester compounds have the highest FD factor of 256, then methyl butyrate with FD factor 64. Compounds of the carboxylic acid group with a low FD of $<16$ are thought to give nuance to the characteristic flavor of Applewood fruit (Apriyantono \& Kumara, 2004).

\subsection{Analysis of the amount of volatile compounds}

The ALC-DCM extract has a class of esters, aldehydes, ketones, and amines higher than other extracts. By comparing the DCM extract as the quality standard for applewood flavor,
ALC-DCM extract has a better flavor quality. In table 1 can be seen it has more ester compounds, namely $28.57 \%$, compared to $13.64 \%$ (Figure $4 \mathrm{~A}$ ). In Figure $4 \mathrm{~B}$, it can be seen that the PCA of the natural compounds of the ALC-DCM extract is an ester group compound. In contrast, the DCM extract is an alcoholic and carboxylic acid compound.

Figure $4 \mathrm{C}$ is an analysis of the total compounds per group. This analysis aims to see to what extent the solvent in maceration effectively attracts the flavor components. As can be seen in table 1, ALC-DCM solvent can produce many esters (58.82\%), aldehydes (60\%), ketones (50\%), and amines (100\%). The LLE technique of ALC-DCM extract can increase the top flavor compound compared to the DCM extract, namely ester by $66.67 \%$ from $35.29 \%$ to $58.82 \%$.

\subsection{Identification of compounds by LC-MS/MS}

The active compound of ALC-DCM extract with considerable molecular weight (MW) that was not detected by GC-MS equipment was then analyzed using LC-MS/MS. There were 30 organic compounds extract ALC-DCM, 16 compounds with a concentration above $1 \%$. The ALC-DCM extract contains
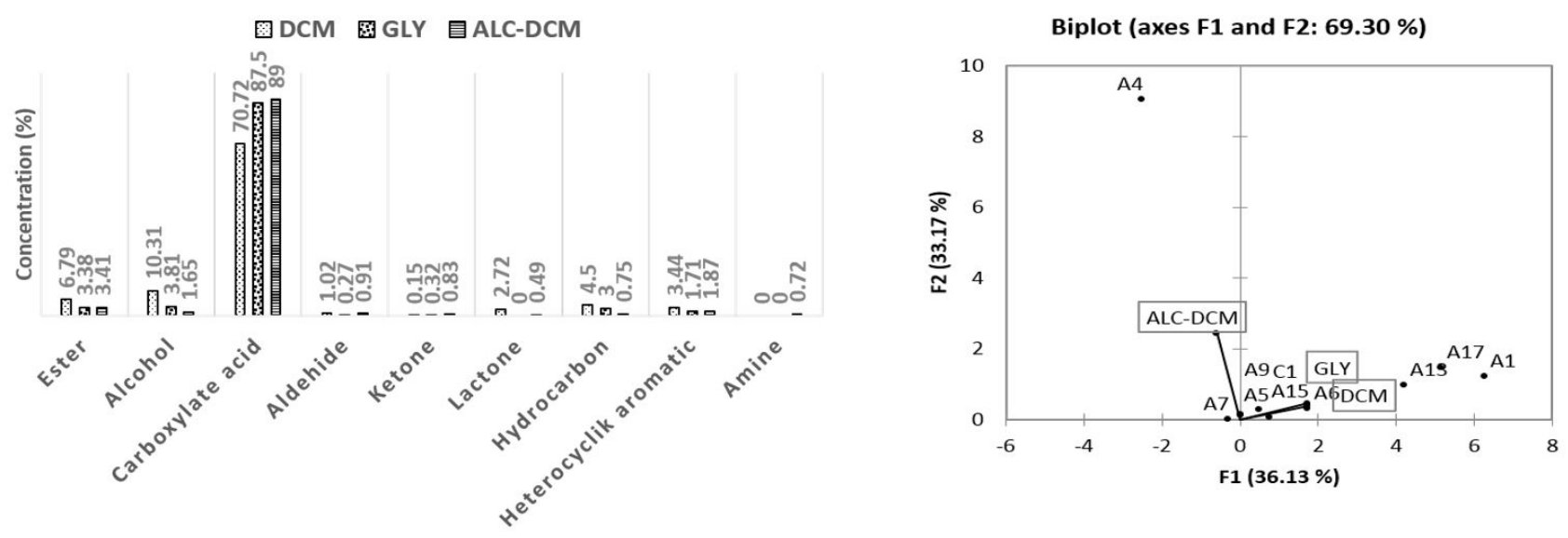

Figure 3. Concentrations of volatile compounds (A) and the PCA analysis for the DCM, GLY, and ALC-DCM extracts (B).

A

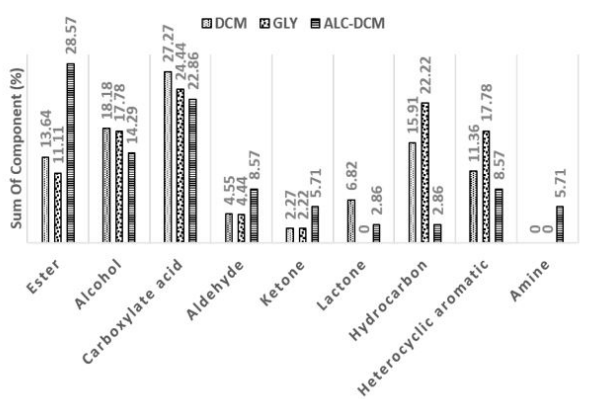

B

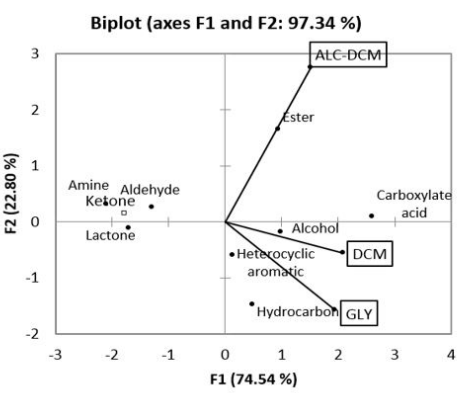

$\mathrm{C}$

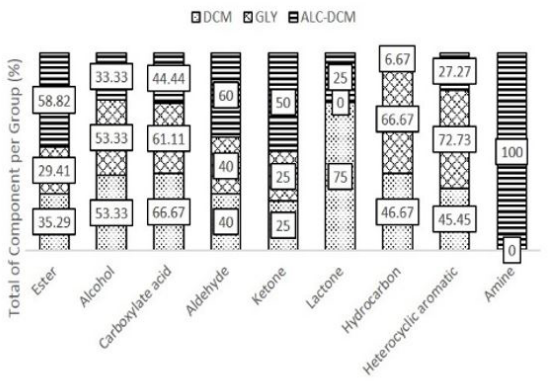

Figure 4. Volatile compounds (A), PCA analysis (B), Total volatile compounds per group of DCM, GLY, ALC-DCM extracts (C). 

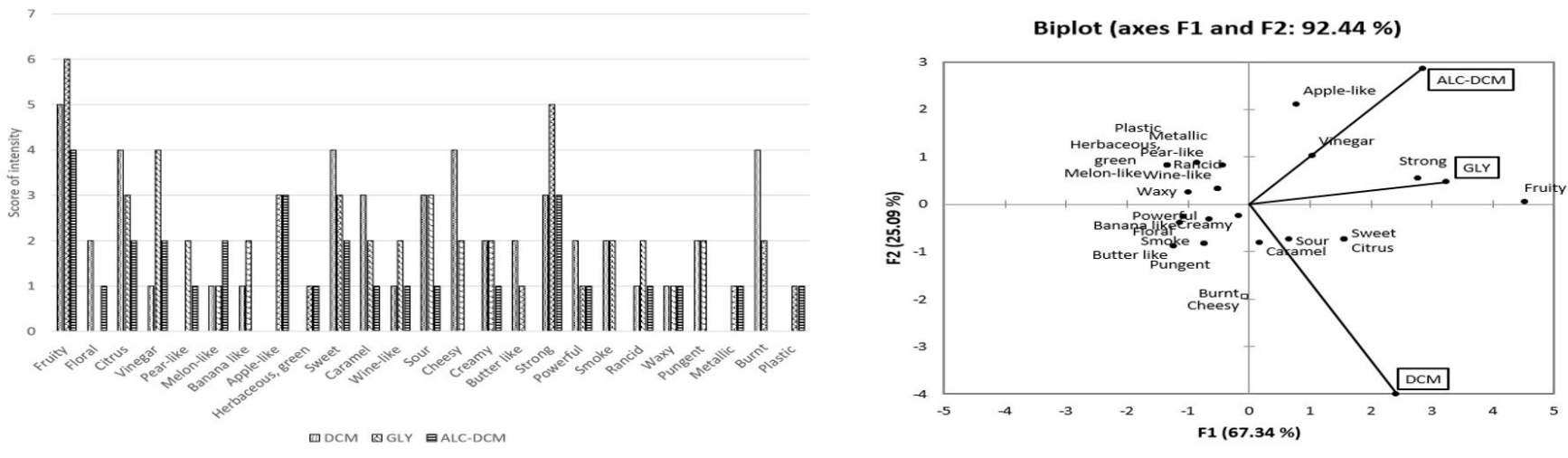

Figure 5. The results of QDA (A) and PCA analysis (B) of the DCM, GLY, and ALC-DCM extracts.

compounds that give the applewood fruit a distinctive aroma. In number 8 , there is a compound 4- (Allyloxy) -2-methyl-2pentanyl acetate from the ester group contributing to the clary, floral, and fruity aroma of applewood fruit.

In general, it can be stated that the components of the compounds in the ALC-DCM extract have the functional potential for health such as the number 24 compound (9Z) -N- (2-Hydroxyethyl) -9-octadecenamide plays a role in diet controlling obesity, compound 3- ((3- hydroxyundecanoyl) oxy] -4- (trimethylazaniumyl) butanoate at number 11 known as Acyl carnitine, is an essential component in the metabolism of fatty acids and in muscle and liver tissue is quite high in concentration. The compound $(9 \mathrm{E}, 11 \mathrm{Z}, 13 \mathrm{E}$, 15Z) -4-oxooctadeca-9,11,13,15-tetraenoic acid at number 13 is lineolic acid, omega 6 unsaturated fatty acid, 18 atoms C. This is in line with the statement (Sukamto, 1999; Pandey et al., 2014; Jayashree \& Londonkar, 2014; Dewi, 2013) regarding the health benefits of Applewood fruit.

\subsection{Sensory analysis}

QDA sensory analysis can assess all sensory properties of a product, the use of limited and trained subjects (Stone, 2004). The QDA sensory analysis results describe 25 specific aromas of the AFE (Figure 5). The specific aroma of fruity, citrus, vinegar, melon-like, sweet, caramel, wine-like, sour, creamy, strong, powerful, and irregular aroma of rancid and waxy appeared in all three types of extracts. Aroma compounds based on sensory analysis: DCM extract is sour, caramel, sweet, and citrus; ALCDCM extract is apple-like, and vinegar; GLY extract is strong and fruity.

\section{Conclusions}

The graded applewood flavor extraction, namely maceration of alcohol and LLE with dichloromethane solvent (ALC-DCM extract), obtained a high yield of a $28.55 \%$ pulp basis. Analysis by GC-MS successfully characterized 91 volatile compounds from AFE. The highest concentrations of volatile compounds in the ALC-DCM extract are the carboxylic acid (89.0\%), followed ester (3.41\%), heterocyclic aromatic (1.87\%), alcohol (1.65\%), aldehyde $(0.91 \%)$, ketone $(0.83 \%)$, hydrocarbon $(0.75 \%)$, amine $(0.72 \%)$, and lactone $(0.49 \%)$.

Based on PCA the amount of compounds, the marker compounds of ALC-DCM extract is the ester group. Aroma compounds based on sensory analysis, the ALC-DCM extract is apple-like, and vinegar. The ALC-DCM extract had better flavor quality than the DCM extract control because it had more ester compounds, namely $28.57 \%$, compared to $13.64 \%$.

There were 30 organic compounds ALC-DCM extract from LC-MS/MS analysis, 16 compounds with a concentration above $1 \%$. ALC-DCM extract as AFE has the potential to be developed as a food flavor because it has a distinctive aroma and high yield.

\section{Acknowledgements}

This research is part of the doctoral scholarship program. Therefore, we would like to express our gratitude to the Indonesian government through the BUDI-DN program in collaboration with the Ministry of Research and Technology/National Research and Innovation Agency and LPDP Ministry of Finance, RI. Our thanks also to PT Firmenich Indonesia for providing standard flavor samples.

\section{References}

Apriyantono, A., \& Kumara, B. (2004). Identifikasi character impact odorants Buah Kawista (Feronia limonia). Jurnal Teknologi dan Industri Pangan, 15, 1. Retrieved from https://repository.ipb.ac.id/ jspui/bitstream/123456789/29778/1/Anton_Apriyantono_identifikasi_ character_2004_No1.pdf

Ardila, T. T., \& Noor, E. (2020). Karakterisasi Flavor Ekstrak Buah Kawista. West Java: Fateta IPB University. Retrieved from https:// repository.ipb.ac.id/handle/123456789/102760

Ayseli, M. T., \& İpek Ayseli, Y. (2016). Flavors of the future: Health benefits of flavor precursors and volatile compounds in plant foods. Trends in Food Science \& Technology, 48, 69-77. http://dx.doi. org/10.1016/j.tifs.2015.11.005.

Berger, R. G. (2009). Biotechnology of flavours-the next generation. Biotechnology Letters, 31(11), 1651-1659. http://dx.doi.org/10.1007/ s10529-009-0083-5. PMid:19609491. 
Dewi, R. (2013). Bioaktivitas Buah Kawista (Limonia acidissima) Bima dan Penentuan Sidik Jarinya Menggunakan Kromatografi Lapis Tipis. West Java: FMIPA, IPB University.

El Hadi, M., Zhang, F.-J., Wu, F.-F., Zhou, C.-H., \& Tao, J. (2013). Advances in Fruit Aroma Volatile Research. Molecules (Basel, Switzerland), 18(7), 8200-8229. http://dx.doi.org/10.3390/molecules18078200. PMid:23852166.

Engel, K. H., \& Tressl, R. (1983). Studies on the volatile components of two mango varieties. Journal of Agricultural and Food Chemistry, 31(4), 796-801. http://dx.doi.org/10.1021/jf00118a029.

Goff, S. A., \& Klee, H. J. (2006). Plant volatile compounds: sensory cues for health and nutritional value? Science, 311(5762), 815-819. http://dx.doi.org/10.1126/science.1112614. PMid:16469919.

Heath, H. B. (1978). Flavor technology - profiles, products, applications. USA: AVI Pub. Co.

Idstein, H., Keller, T., \& Schreier, P. (1985). Volatile constituents of mountain papaya (Carica candamarcensis, syn. C. pubescens Lenne et Koch) fruit. Journal of Agricultural and Food Chemistry, 33(4), 663-666. http://dx.doi.org/10.1021/jf00064a024.

Jayashree, V. H., \& Londonkar, R. L. (2014). Comparative phytochemical studies and antimicrobial potential of fruit extracts of Feronia limonia Linn. International Journal of Pharmacy and Pharmaceutic, 6(1), 731-734.

Laarsen, M., \& Poll, L. (1990). Quick and simple extraction method for analysis of aroma compounds in fruit products. In Y. Bessiere \& A. F. Thomas (Eds.), Flavour science and technology. England: John Wiley \& Son's Ltd.

Lindawati, T. (1995). Ekstraksi, Identifikasi dan Karakterisasi Komponen Flavor Kulit dan Hati Nenas (Ananas comusus (L) Merr.). Fateta IPB.

MacLeod, A. J., \& Pieris, N. M. (1981). Volatile flavor components of wood apple (Feronia limonia) and a processed product.
Journal of Agricultural and Food Chemistry, 29(1), 49-53. http://dx.doi.org/10.1021/jf00103a013.

Martunus \& Helwani, Z. (2006). Kecepatan Pengadukan Minimum Sistem Refinery Palm Oil (RPO)-Asam Asetat-Air dalam Ekstraktor Tangki Berpengaduk (ETB). J. Optimum, 7(2), 174.

Ormeño, E., Goldstein, A., \& Niinemets, Ü. (2011). Extracting and trapping biogenic volatile organic compounds stored in plant species. Trends in Analytical Chemistry, 30(7), 978-989. http://dx.doi.org/10.1016/j.trac.2011.04.006.

Pandey, S., Gouri, S., \& Rajinder, K. G. (2014). Evaluation of nutritional, phytochemical, antioxidant and antibacterial activity of exotic fruit "Limonia acidissima". Journal of Pharmacognosy and Phytochemistry, 3(2), 81.

Septiana, E. E. (1995). Ekstraksi, Identifikasi dan Karakterisasi Flavor Durian (Durio zibethinus Murr.). Fateta IPB.

Setyaningsih, D., Apriyantono, A., \& Sari, M. P. (2010). Analisis Sensori untuk Industri Pangan dan Agro. Bogor: IPB Press, IPB University Bogor.

Stone, H. S. J. (2004). Sensory evaluation practices (3rd ed.). USA: Elsevier.

Sukamto, L. A. (1999). Morfogenesis berbagai eksplan kawista (Limonia acidissima L.) yang ditumbuhkan secara kultur. Jakarta: LIPI.

Yamaguchi, K., Nashimura, O., Toda, H., Mihara, S., \& Shibamoto, T. (1993). Chemical studies on tropical fruits. In G. Charalambous \& G. Inglett (Eds.), Instrumental analysis of food, recent progress (Vol. 2). New York: Academic Press.

Zegler, J. (2012). 2012 new product development survey. Troy, MI: Beverage Industry. 